\title{
Inkluzivní prostředí v reflexích učitelů - regionální sonda
}

\section{Inclusive Environment in Teachers" Reflections \\ - a Regional Probe}

Helena Vomáčková1 , Univerzita J. E. Purkyně v Ústí nad Labem, Ústí nad Labem

\begin{abstract}
Abstrakt
Př́spěvek zkoumá výpovědi učitelů o úrovni inkluzivní orientace na třech základních školách, kde působí. Cílem bylo pomocídotazníkového šetření ověřit zpo̊sob kvantifikace úrovně inkluze v praxi a porovnat výsledky tří sledovaných oblastí (inkluzivní kultura, politika, praxe) a v rámci nich šesti podoblastí inkluze (budování inkluzivní komunity, stanovení inkluzivních hodnot, vytváření školy pro všechny, podpora různorodosti, organizace učení, mobilizace zdrojů). Součástí šetření bylo rovněž vzájemné porovnání škol na základě reflexí učitelů. Data byla získána pomocí dotazníkového šetření on-line a zpracována pomocí základních ukazatelů popisné statistiky. Výzkumným úkolem bylo získat výchozí data pro posilování reálného procesu inkluze na vybraných školách. Ze získaných výsledků lze usuzovat na oblasti a podoblasti inkluze, které jsou učiteli vnímány jako problematické a které představují bariéry v procesu nastavení inkluzivně př́znivého prostředí v praxi škol.
\end{abstract}

\section{Klíčová slova}

inkluzivní prostředí škol, ukazatelé inkluze, oblasti a podoblasti inkluze, základní ukazatele popisné statistiky, průměrné hodnoty ukazatelů

\section{Abstract}

This paper examines teachers' statements about the level of inclusive orientation at the three primary schools where they work. The aim was to verify the method of quantification of the level of inclusion in practice and compare the results of three monitored areas (inclusive culture, politics, practice) and within them six sub-areas of inclusion (building an inclusive community, setting inclusive values, creating a school for all, promoting diversity, learning organization, resource mobilization). The survey also included a comparison of schools based on teacher reflections. Data were obtained employing an online questionnaire survey and processed using basic indicators of descriptive statistics. The research task was to obtain initial data for strengthening the real process of inclusion in selected schools. From the obtained results it is possible to deduce the areas and sub-areas of inclusion, which are perceived by teachers as problematic, and which represent barriers in the process of setting an inclusive environment in school practice.

\section{Keywords}

inclusive school environment, inclusion indicators, areas and sub-areas of inclusion, basic indicators of descriptive statistics, average values of indicators

\section{Úvod}

Příspěvek se zabývá analýzou výpovědí učitelů o úrovni inkluzivního prostředí tř́ základních škol, kde pedagogicky působí. Využívá k tomu standardizovaného dotazníku Bootha a Aiscowa (2011), který mapuje ve třech oblastech ukazatele inkluze. Cílem příspěvku je zjistit a porovnat názory učitelů z výzkumně

1 Kontaktní osoba: helena.vomackova@ujep.cz 
dostupných škol, nebot́ přístup učitelů a jejich osobnostní nastavení lze pro implementaci inkluze považovat za klíčové (Tannenbergerová, 2016). Jakkoli nelze vyjádření učitelů očistit o snahu vyjadřovat se - byt' anonymně - o své škole v lepším světle, než odpovídá objektivní realitě, poskytují významnou zpětnou informaci, s níž lze dále pracovat. Považujeme ji za první krok k vlastní sebereflexi škol, zejména k zamyšlení, proč se v určitých oblastech nedaří, k pochopení silných a slabých stránek, k realizaci žádoucího partnerství, nejen mezi učiteli a ředitelem, ale i mezi učiteli a rodiči a v neposlední řadě mezi žáky samotnými. Bez poctivého přístupu školy a otevřené atmosféry, kde např. učitelé nemají strach hovořit o tom, co sami nezvládají a co je vyčerpává, se inkluzivně příznivé prostředí pro žáky nedá vytvořit. Příspěvek uvádí komentované výsledky provedené analýzy doplněné řadou otevřených otázek. Jejich budoucí zodpovězení napoví, zda se uvedené školy teoretickému modelu inkluze (Svoboda, Říčan, Morvayová, \& Zilcher, 2015) přiblíží či nikoli.

\section{Současný stav poznání}

Od zákonného zakotvení inkluze v rámci regionálního školství v České republice (Adamus et al. 2016) uplyne v září 2021 pět let. Během nich byla realizována značná část implementačních a podpůrných projektů, která byla provázena polemikami nejen široké učitelské veřejnosti ale i veřejnosti rodičovské. Teoretické požadavky inkluze byly konfrontovány s praktickými možnostmi škol a jejich pedagogů, vytvořily se názorově protichůdné tábory, argumentovalo se pro i proti procesu probíhající inkluze. Nelze přehlédnout, že tento proces byl zahájen v době, kdy již proběhla změna ve struktuře hodnot dospělé populace ČR (Prudký, 2009) a kdy se celospolečensky posílily separační tendence. Potvrzuje to i studie Vomáčkové a Cihláře (2015), která na příkladu 14 krajů ČR dokladuje rozdíly mezi nimi z hlediska kumulace dílčích skupin obyvatel, což signalizuje oslabování původní diverzity občanů v daných oblastech. Kumulace nezaměstnaných s nezaměstnanými, nevzdělaných s nevzdělanými, chudých s chudými a naopak, je jednou z limit při tvorbě inkluzivního prostředí v jediném ze sektorů národního hospodářství - ve školství. Vytvořit heteronomní třídní kolektiv žáků v oblasti, kde žijí např. výlučně majetní obyvatelé nebo naopak sociálně slabí, představuje v současnosti ČR nepřekonatelný problém. Jinakost v tomto smyslu byla odstraněna. Např. základní škola na Královských Vinohradech a v ústeckých Předlicích tak představují dva zcela odlišné světy, ačkoli v rámci jediného povinného vzdělávání. Výzkumy přitom dokazují, že kontakt s jinakostí a rozmanitost podnětů vede k akceleraci lidského potenciálu (Zilcher, \& Říčan, 2014; Petlák, 2009).

Pojetí inkluze, postavené na různorodosti a jinakosti je tím bezpochyby dotčeno a může být v praxi značně vzdáleno teoreticky formulovaným vizím inkluzivní školy (Svoboda Říčan, Morvayová, \& Zilcher, 2015), stejně tak jako naplnění jednoho z cílů inkluzivního vzdělávání „umožnit všem rovný př́istup ke vzdělávání“ (Kratochvílová, 2013, s. 13). Přesto je pokrok v zavádění inkluzivních opatření patrný a lze ho pozorovat např. v oficiální statistice MŠMT (2021), viz tabulka 1. Z ní je patrný nárůst žáků integrovaných do běžných škol s různými typy postižení. Největší dynamiku nárůstu vykázala zejména v posledních čtyřech letech sledovaného devítiletého mezidobí integrace žáků s vadami řeči a s poruchami chování. Uvedené skutečnosti mění nároky na učitele běžných škol, kteří pracují tzv. v první linii a bez jejichž součinnosti nelze inkluzi do praxe implementovat (Vomáčková et al., 2015). Učitelé představují klíčového nositele inkluze. 


\begin{tabular}{|c|c|c|c|c|c|c|}
\hline & Druh postižení & $2010 / 11$ & $2015 / 16$ & $\begin{array}{l}\text { Nárůst } \\
\text { o\% }\end{array}$ & $2019 / 20$ & $\begin{array}{l}\text { Nárůst } \\
\text { o\% }\end{array}$ \\
\hline $\begin{array}{l}\text { Indivi } \\
\text { celker }\end{array}$ & uálně integrovaní žáci & 36226 & 49225 & 35,9 & 84010 & 131,9 \\
\hline & mentálně postižení & 1119 & 1690 & 51,0 & 3203 & 186,2 \\
\hline & sluchově postižení & 581 & 705 & 31,3 & 783 & 34,8 \\
\hline & zrakově postižení & 401 & 519 & 29,4 & 677 & 68,8 \\
\hline & s vadami řeči & 963 & 2976 & 109,0 & 7473 & 676,0 \\
\hline v & tělesně postižení & 977 & 926 & $-5,2$ & 981 & 0,4 \\
\hline tom & s více vadami & 703 & 841 & 19,6 & 2854 & 306,0 \\
\hline & s poruchami učení & 28370 & 32830 & 15,7 & 48576 & 71,1 \\
\hline & s poruchami chování & 2374 & 6559 & 176,3 & 16903 & 612,0 \\
\hline & $\begin{array}{l}\text { s lékařskou diagnózou } \\
\text { autismus }\end{array}$ & 738 & 2179 & 195,3 & 2560 & 246,9 \\
\hline
\end{tabular}

Tab. 1 Nárůst individuálně integrovaných žáků v mezidobí 2010/11 (bazický rok) až 2019/20

Je třeba proto znát názory učitelů, jejich výhrady, ale i předsudky, obavy apod., aby bylo možné ovlivňovat jejich postoje a tím i jejich chování(Ajzen, \& Fishbein, 2005). Bez jejich pochopení společného vzdělávání a bez jejich pozitivního působení nelze očekávat nap̌r. př́źnivé postoje intaktních žáků k jejich spolužákům s postižením (Boer et al., 2014). Položili jsme si tedy výzkumnou otázku, zda na zvolených školách po pěti letech od oficiálního startu inkluze, převažuje u jejich učitelů spíše pozitivní nebo negativní vnímání inkluzivního prostředí na jejich školách.

Tvorba inkluzivního prostředí ve školské praxi je zrovna tak otázkou dobré vůle „přidělávat si práci“ a reflektovat potřebu změn u sebe sama jako vzdělavatele, jako otázkou odborného studia. Z tohoto pohledu je obecně tvorba inkluzivního prostředí vždy zatěžující, a proto i u řady pedagogů neoblíbená. Pokud učitel působil dlouhodobě např. pouze jako „předkladač informací“, je z hlediska efektivní inkluze nucen tento stereotyp přetavit do podoby „průvodce žáka“ v jeho objevování vlastních dispozic, v hledání cest k řešení jeho problémů, v překonávání chybných vzorců chování apod. Při inkluzi převyšuje důraz na žáka samého, na jeho „přečtení“ učitelem, jeho podněcování, vedení k porozumění sobě samému, nutně důraz na vědomosti a znalosti žáka, zejména z hlediska kvantity. Např. Spilková a Tomková (2010) hovoří v tomto kontextu o „pečujícím učiteli“. Vomáčková a Chytrý (2019) upozorňují na důležitost vnímání učitele žákem coby „spojence“ a vzdělavatele, který je čitelný a má důvěru žáků. Klíčovou roli učitelů v procesu inkluze podtrhují i další autoři (např. Šauerová, Špačková, \& Nechlebová, 2012; Mühlpachr, 2008), někteří hovoří o jejich „proinkluzivních“ kompetencích a sledují jejich dopad na postoje žáků (Zilcher, \& Svoboda, 2019). Učitelé v podstatné míře rozhodují o tom, zda lze školu považovat za inkluzivní či nikoli. V ČR dosud žádná databáze indikátorů, které by objektivně umožňovaly měřit celkovou „inkluzivitu“ škol neexistuje. K dispozici jsou jen určité nástroje k měření otevřenosti školy vůči inkluzivnímu vzdělávání (Lukas, 2012). Mezi řadou autorů panuje shoda, že inkluzivní školu lze charakterizovat jako „školu v pohybu“ (např. Landin, 2010; Tannenbergerová, 2013; Mukopahdyay, 2014; Svoboda et al., 2015), jiní považují za klíčové získání certifikátu „Férová škola“, nebot́ tvrdí, že absolvování náročných zkoušek a testování samo o sobě vypovídá o proinkluzivním směřování školy a jejích pedagogů. Za systémový přístup k indikaci inkluzivní školy lze ale považovat jen využití komplexního souboru indikátorů k měření inkluzivních hodnot, at' už ve zjednodušené verzi (Tannenbergerová, Svoboda, Zilcher, \& Smolík, 2015) nebo v původním rozsahu (Booth, \&Ainscowa, 2007; Hájková, \& Strnadová, 2010). Tímto přístupem byla inspirována i předkládaná studie. 


\section{Metoda}

Cílem sondy bylo získat aktuální poznatky o vnímání inkluze 146 učiteli na třech dostupných základních školách Ústeckého kraje, které byly po oslovení ochotny spolupracovat. Zastoupení učitelů bylo u zapojených škol vyvážené (ZŠ Litvínov 31 \%, ZŠ Most 35 \%, ZŠ Ústí 34\%). K šetření byl použit jako výzkumný nástroj dotazník na bázi ukazatelů inkluzivně orientované školy (Booth, \& Ainscow, 2007). Dotazník respektoval rozložení do tří oblastí (A-budování inkluzivní kultury, B-inkluzivní politika, C-rozvíjení inkluzivní praxe), které byly strukturovány do šesti podoblastí (AK-budování komunity, AH-stanovení inkluzivních hodnot, BV-vytváření školy pro všechny, BR-podpora různorodosti, C0-organizace učení, CZ-mobilizace zdrojů). Samotný dotazník obsahoval 44 položek (Svoboda, \& Zilcher, 2019), kde učitelé vyjadřovali svá stanoviska pomocí čtyřstupňové škály (4=rozhodně souhlasím, 3=spíše souhlasím, 2=spíše nesouhlasím, 1=rozhodně nesouhlasím). S ohledem na pandemickou situaci byl po předchozí instruktáži ředitelů škol poskytnut jejich pedagogickým pracovníkům dotazník v on-line verzi v 1. čtvrtletí r. 2021. Dotazník byl anonymní a z hlediska etiky výzkumu nebylo nutno přijmout žádná opatření. Jsme si vědomi, že vzhledem k obecné tendenci nadhodnocovat (tj. realitu verbalizovat blíže optimu), získané výsledky nelze přeceňovat.

Administrace dat probíhala v excelu, kde byl vytvořen pro každého respondenta přepisem z dotazníku jeden excelovský řádek ( $v$ členění dle škol a dle výše uvedených podoblastí). Bylo tak vytvořeno 146 řádků, které obsahovaly 44 datových sloupců (z toho za podoblast AK-7, AH-6, BV-6, BR-9, C0-11, CZ-5). Takto strukturovaná data byla zpracovávána hromadně. Postup zpracování byl ovlivněn požadavkem jednoduchosti (aby školy neodradila při využití výsledků šetření jejich teoreticko-vědecká nesrozumitelnost) a požadavkem přiměřené vypovídací schopnosti výstupů. Jako základní statistický nástroj byl proto využit aritmetický průměr, který byl zjištován ve třech úrovních: v úhrnu všech respondentů a všech položek jako celkové skóre, dále za každou oblast školního prostředí jako dílčí skóre a nakonec za každou dotazníkovou položku jako individuální skóre. Dílčí skóre bylo komparováno v rámci škol zapojených do šetření. Čím vyšších hodnot bylo v průměru dosaženo, tím vyšší mínění učitelé vyjádřili o úrovni inkluze na své škole. Naopak, čím nižších hodnot dosáhlo skóre, tím problematičtěji učitelé vnímali inkluzivní prostředí na své škole. Prostřednictvím směrodatné odchylky byli učitelé sledovaného vzorku rozděleni do pěti skupin dle úrovně svého celkového vnímání inkluzivní orientace školy:

- výrazně pozitivní (více než Ø + 2SD),

- spíše pozitivní $(\varnothing+\mathrm{SD}$; $+2 \mathrm{SD}>)$,

- neutrální postoj $(<\emptyset-\mathrm{SD} ; \emptyset+\mathrm{SD}>)$,

- spíše negativní (Ø-2SD; Ø-SD>),

- výrazně negativní (méně než Ø - 2SD).

V rámci stanoveného cíle byl formulován předpoklad, že v reflexích učitelů budou převažovat pozitivní vyjádření, která se pomítnou u zapojených ZŠ do pozitivního hodnocení alespoň ve dvou oblastech ze tří sledovaných. Jelikož se jednalo o školy z Ústeckého kraje, předpokládali jsme, že u všech škol bude rozložení výsledků ve všech šesti podoblastech obdobné.

\section{Výsledky}

Výsledky šetření lze rozdělit do tří kroků. V prvním kroku bylo zjišttováno celkové skóre učiteli reflektovaného inkluzivního prostředí. Jeho hodnota dosáhla za všech 146 respondentů v úhrnu 44 položek dotazníku hodnoty 3,32. Celkové skóre lze využít jako mezní hodnotu při posuzování dílčích oblastí inkluze a položek dotazníku. Celý vzorek respondentů přitom vykázal při směrodatné odchylce 0,24 normální rozložení četností dle příslušnosti ke skupině - viz obr. 1:

- více než 3,80 výrazně pozitivní vyjádření,

- 3,79 - 3,56 spíše pozitivní vyjádření,

- 3,55 - 3,07 neutrální postoj,

- 3,06 - 2,83 spíše negativní vyjádření,

- méně než 2,82 výrazně negativní vyjádření. 


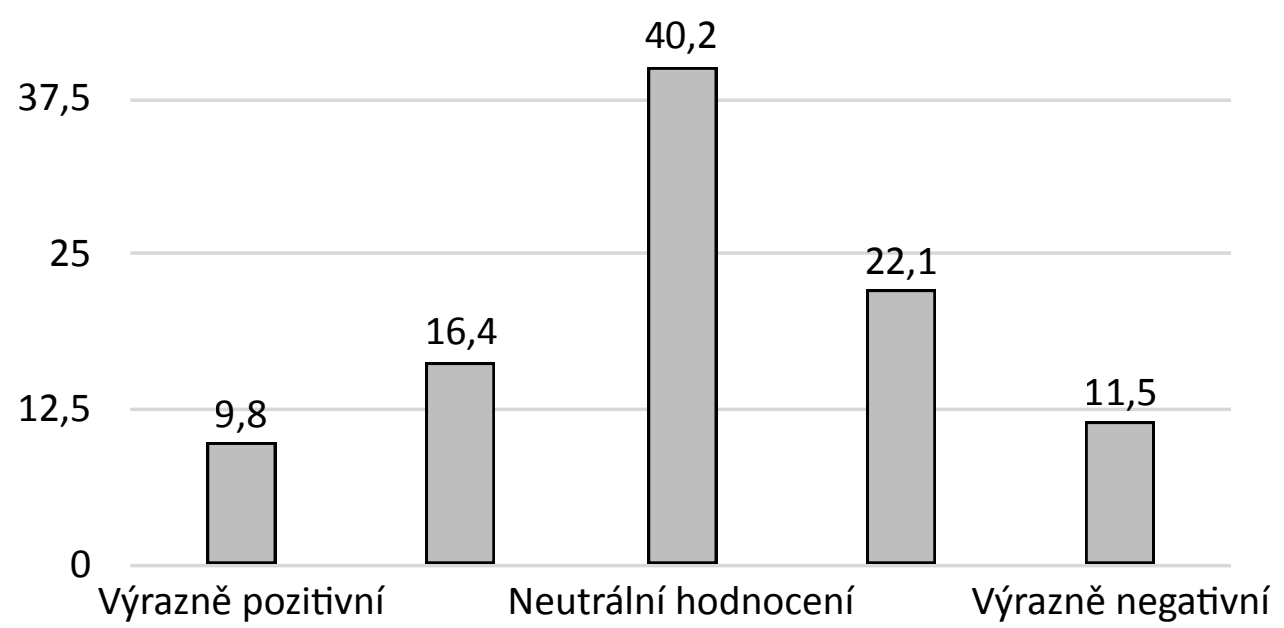

Obr.1 Relativní rozložení četností výrokŭ učitelŭ

Výše uvedený graf demonstruje, že nejčetněji vyjadřovali respondenti neutrální stanovisko (40,2 \%), k problematickému hodnocení inkluzivního prostředí se přiklonilo 33,6 \% učitelů a k pozitivnímu vidění inkluzivního prostředí se přihlásilo 26,2\% z celkového počtu respondentů.

V druhém kroku bylo zjišt́ováno dílčí skóre. Ukazatelé inkluzivní orientace seskupení do šesti podoblastí v komparaci jednotlivých škol vykázali následující hodnoty - viz tabulka 2.

\begin{tabular}{|l|c|c|c|c|}
\hline $\begin{array}{r}\text { Sledované podoblasti } \\
\text { inkluzivního prostředí }\end{array}$ & $\begin{array}{c}\text { Dílčí skóre } \\
\text { podoblasti }\end{array}$ & ZŠ Litvínov & ZŠ Most & ZŠ Ústí \\
\hline AK budování komunity & $\mathbf{3 , 0 4}$ & 2,82 & 3,15 & 3,15 \\
\hline AH inkluzivní hodnoty & $\mathbf{3 , 0 8}$ & 2,97 & 3,17 & 3,11 \\
\hline BV škola pro všechny & $\mathbf{3 , 5 6}$ & 3,36 & 3,69 & 3,61 \\
\hline BR podpora různorodosti & $\mathbf{3 , 4 1}$ & 3,35 & 3,37 & 3,50 \\
\hline CO organizace učení & $\mathbf{3 , 1 6}$ & 3,33 & 2,91 & 3,24 \\
\hline CZ mobilizace zdrojů & $\mathbf{3 , 0 6}$ & 2,95 & 2,89 & 3,33 \\
\hline
\end{tabular}

Tab. 2 Dílčí skóre jednotlivých podoblastí v rámci sledovaných škol

Z tabulky 2 vyplývá, že mezní hodnota celkového skóre 3,32:

- byla překročena u dvou podoblastí ze šesti sledovaných, přičemž obě byly z oblasti B-inkluzivní politika. Jak v úhrnu, tak u jednotlivých škol zde učitelé charakterizovali příznivější inkluzivní orientaci svých škol než průměrnou. V podoblasti BV-škola pro všechny dosáhla nejvyššího dílčího skóre ZŠS Most (3,69), v podoblasti BR podpora různorodosti vykázala nejvyšší dílčí skóre ZS Ústí $(3,50)$.

- nebyla dosažena ve čtyřech podoblastech, které naplňovaly oblast A-inkluzivní kultura a oblast C-inkluzivní praxe. V úhrnu vykázala nejnižší dílčí skóre podoblast AK-budování inkluzivní komunity (ze škol pak ZŠ Litvínov (2,82) a CZ-mobilizace zdrojů (ze škol pak ZŠ Most (2,89).

Tabulka 2 rovněž dokladuje, že dle mezních hodnot normálního rozložení do skupin:

- byla jedinou podoblastí s vysokou mírou pozitivního vnímání inkluzivní orientace školy (nad hodnotu 3,56 včetně) podoblast BV-škola pro všechny, kterou svým skóre převýšila ZŠ Most $(3,69)$ a ZŠ Ústí $(3,61)$.

- byly vykázány dvě podoblasti s vysokou mírou negativního vnímání inkluzivní orientace (pod hodnotou 3,06 včetně), a to podoblast AK-budování inkluzivní komunity, přičemž skóre pod touto hodnotou zde vykázala ZŠ Litvínov (2,82) a dále podoblast CZ-mobilizace zdrojů, přičemž skóre pod touto hodnotou vykázala ZŠ Most $(2,89)$ a ZŠ Litvínov (2,95). 
Ve třetím kroku bylo zjištováno individuální skóre jednotlivých položek dotazníku. Na základě analýzy byly vymezeny položky s vysokou mírou pozitivního vnímání inkluze (nad hodnotu 3,56 včetně) a naopak položky s vysokou úrovní negativního vnímání inkluze (pod hodnotu 3,06 včetně) - viz graf 2. Jak vyplývá z grafu, jedinou položkou s vykázanou vysokou mírou pozitivního vnímání byla položka BR9 - Jsou minimalizovány případy agrese či šikany. Naopak vysoká míra negativního vnímání z hlediska inkluze byla vykázána hned u devíti položek:

CZ5 Školní zdroje jsou spravedlivě rozdělovány a využívány ve prospěch inkluze CZ4 Využívají se zdroje z celé komunity

CZ3 Pedagogové školy vytvářejí zdroje na podporu učení a zapojení všech žáků CZ2 PIně se využívají odborné znalosti pedagogů i ostatních zaměstnanců školy CZ1 Rozdíly mezi žáky se využívaji jako zdroj pro výuku a učení CO11 Všichni žáci se účastní mimoškolních aktivit CO10 Domácí úkoly, pokud jsou zadávány, přispívají k učení všech žáků CO9 Asistenti pedagoga podporují učení a zapojení všech žáků CO8 Učitelé provádějí plánování, výuku a hodnocení kooperativně CO7 Kázeň žáků je založena na uvědomělosti a na vzájemné ohleduplnosti a úctě CO6 Hodnocení přispívá k dobrým výsledkům všech žáků CO5 Žáci při učení vzájemně spolupracuj CO4 Žáci jsou aktivně zapojeni do vlastního procesu učení $\mathrm{CO} 3 \mathrm{~V}$ hodinách se rozvijí porozumění odlišnostem CO2 V hodinách se sleduje a podporuje zapojení všech žáků CO1 Výuka je plánována tak, aby se zapojili a měli z ní prospěch všichni žáci BR9 Jsou minimalizovány případy projevů agrese či dokonce šikany ve školním prostredí BR8 Jsou minimalizovány překážky $v$ docházce do školy

BR7 Jsou minimalizovány případy vyloučení ze školních aktivit z kázeňských důvodů BR6 Podpora pro ty, kteří se učí vyučovací jazyk jako cizí jazyk, je koordinována s podporou učení BR5 Cíle a mechanismy podpory osobnostního rozvoje žáků jsou v souladu se ŠVP a s cíli v podpoře učení

BR4 Je používán provádějící předpis pro podporu naplnění vzdělávacích potřeb žáků BR3 Koncepce „speciálních vzdělávacích potřeb“ žáků jsou inkluzivní BR2 Činnosti v oblasti rozvoje zaměstnanců napomáhají zaměstnancům školy reagovat na různorodost studentů BR1 Všechny formy podpory různorodosti jsou koordinovány

BV6 Škola sestavuje učební skupiny tak, aby byli zapojeni a doceněni všichni žáci BV5 Všem novým žákům se pomáhá, aby si ve škole zvykli

BV4 Škoda dbá na to, aby byly její prostory fyzicky dostupné všem osobám BV3 Škola dbá na to, aby přijímala všechny žáky ze své spádové oblasti BV2 Všem novým zaměstnancům školy je aktivně napomáháno, aby si ve škole zvykli BV1 Jmenování a mechanismy ovlivňující kariérový postup pedagogů jsou spravedlivé

AH6 Škola se snaží minimalizovat všechny formy diskriminace nebo nerovných šanci AH5 Pedagogové se snaží odstraňovat překážky v učení a v zapojení žáků ve všech aspektech činnosti školy. AH4 Žáci i pedagogové se k sobě chovají jako člověk k člověku a také se vzájemně ctí a respektují se ve svých "rolích". AH3 V̌̌ichni žáci jsou oceňováni.

AH2 Myšlenka inkluze je sdílena pedagogy, žáky, rodiči i ostatními zaměstnanci školy. AH1 Všichni žáci jsou motivováni a podporováni v tom, aby dosáhli úspěchu. AK7 Do školy se zapojují všechny místní komunity AK6 Zaměstnanci školy a členové správního orgánu dobře spolupracují AK5 Mezi pedagogy školy a rodiči žáků existuje partnerský vztah AK4 Pedagogové a žáci spolu jednají s úctou AK3 Pedagogové a další zaměstnanci školy mezi sebou dobře spolupracují AK2 Žáci si vzájemně pomáhají AK1 Každý se cítí ve škole přijímán a vítán (škola je svým okolím vnímána jako otevřená)

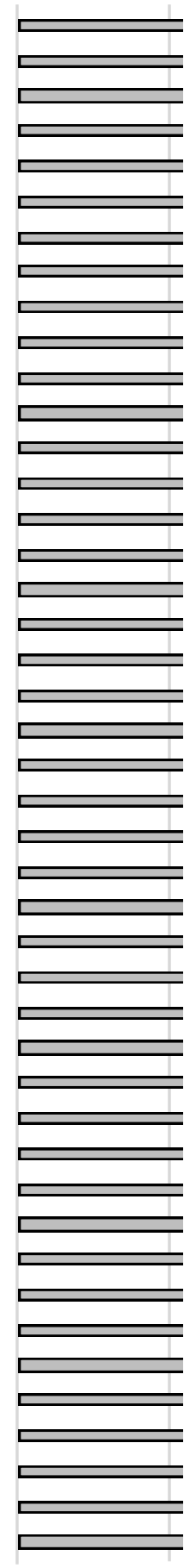

0,5

Graf 2 Výsledná skóre jednotlivých výroků

AK5 Mezi pedagogy školy a rodiči žáků existuje partnerský vztah (skóre naznačuje nesoulad rodiny a školy, který je jednou z nepodkročitelných položek inkluze (Vomáčková et al., 2019),

AK7 Do školy se zapojují všechny místní komunity (skóre dokumentuje osamocenost školy v úsilí o inkluzi v daných lokalitách),

AH1 Všichni žáci jsou motivováni a podporováni v tom, aby dosáhli úspěchu (skóre ukazuje, že existují rozdíly v podpoře jednotlivých žáků), 
AH2 Myšlenka inkluze je sdílena pedagogy, žáky, rodiči i ostatními zaměstnanci školy (skóre vypovídá o vědomí nejednotného postupu),

AH3 Všichni žáci jsou oceňováni (skóre upozorňuje na slabiny v hodnocení a oceňování všech žáků),

BV1 Jmenování a mechanismy ovlivňující kariérový postup pedagogů jsou spravedlivé (skóre dokladuje, že učitelé nejsou přesvědčení o nastavení spravedlivých pravidel a jejich dodržování na svých školách),

C011 Všichni žáci se účastní mimoškolních aktivit (skóre nepotvrzuje soudržnost žákovského kolektivu mimo školu),

CZ1 Rozdíly mezi žáky se využívají jako zdroj pro výuku a učení (skóre odhaluje obtížnost práce s jinakostí v edukačním procesu),

CZ4 Využívají se zdroje z celé komunity (skóre upozorňuje na jiné preference, než je povinné vzdělávání v daných lokalitách).

\section{Diskuse}

Výstupy námi realizované sondy potvrzují, že proces zavádění inkluze do školské praxe je složitou a dlouhodobou záležitostí, kterou nelze zvládnout za pětileté období (Ainscow, César, 2006). Náš předpoklad, že učitelé budou ve svých hodnoceních inkluzivního prostředí na svých školách spíše pozitivní, nebyl naplněn. Dle zijištěné hodnoty celkového skóre (3,32) a směrodatné odchylky $(0,24)$ převýšila v úhrnu nesouhlasná stanoviska učitelů (33,36 \%) stanoviska souhlasná (26,2 \%). Lze se domnívat, že příčinou jsou přetrvávající bariéry a neodpovídající nastavení jak vnějších, tak vnitřních podmínek edukace. Z hlediska dílčích skóre byl předpoklad naplněn pouze v případě oblasti B-inkluzivní politika, zato ale v obou jejích částech a u všech tří sledovaných škol. Hlubší analýza pomocí individuálních skóre ukazuje, že ani v jedné z 15 položek oblasti B neklesla hodnota skóre pod číslo tři a byla v průměru hodnocena všemi pedagogy pozitivně a celkem vyrovnaně. Při porovnání škol pomocí dílčích skóre se jako nejpříznivější jeví proinkluzivní prostředí na ZŠ Ústí (ani v jedné z podoblastí nevykázalo dílčí skóre pod kritickou hodnotou 3,06), následuje ZŠ Most (vykázalo dílčí skóre pod kritickou hodnotou dvakrát, vždy v oblasti C Mobilizace zdrojů) a nejméně příznivé proinkluzivní prostředí bylo indikováno na ZŠ Litvínov (pod kritickou hodnotou se ocitlo třikrát, a to v obou částech oblasti A Inkluzivní kultura a jedné části oblasti C Mobilizace zdrojů).

Na základě analýzy individuálních skóre, v individuálním rozložení všech 44 položek dotazníku, jsme specifikovali odpověd'na položenou výzkumnou otázku. Měřeno př́isnějším kritériem pomocí směrodatné odchylky je odpověd’záporná v poměru jedna kladná odpověd’ku devíti záporným odpovědím - viz kapitola 4. Měřeno méně přísným kritériem pomocí celkového skóre $(3,32)$ je poměr kladných a záporných odpovědí17:27, což potvrzuje zápornou odpověd' na výzkumnou otázku.

Za diskusi rozhodně stojí devět položek s nejnižším hodnocením:

- Položka C011 Všichni žáci se zúčastňují mimoškolních aktivit (2,24) vypovídá o slabé pozici školy, jako organizátora mimoškolních aktivit. Zde je třeba si klást otázky, do jaké míry jde o aktivity pro žáky zajímavé, v jakém rozsahu a frekvenci jsou pořádány, i jak jsou organizovány. Tato položka vyjadřuje míru identifikace se školou, sounáležitost s ní a je náznakem toho, zda se podařilo učitelům vytvořit z žáků tým, kde stojí za to, být na akci př́tomen, protože je tam kamarád-spolužák (Pettigrew, \& Trop, 2008). Pokud je účast na takové akci pro žáka jen nudnou povinností, není divu, že se jí snaží vyhnout. Reflexe školy by měla v tomto případě vést k zamyšlení, zda nejsou tyto akce jen formální záležitostía „odškrtnutou čárkou“.

- Položka AK7 Do školy se zapojují všechny místní komunity $(2,42)$ svědčí o vnějším zájmu či nezájmu komunity o školu, kterou ve spádové oblasti má. Stejně jako v předchozím případě, ale s daleko větším důrazem se tu promítá vliv regionu či oblasti, v níž se škola nachází. Jestliže lze odhadnout, že u položky C011 má škola v rukou cca 85\% úspěchu, tak v případě položky AK7 to může být zastoupení přesně opačné. Vyjádření pedagogů tak v sobě nese stigma „oni na nás kašlou“ a rozhodně upozorňuje na daleko větší očekávání, které učitelé projevují z hlediska spolupráce komunity a školy, než které se jim dostává. V případě uvedených tří ZŠ zřejmě neplatí komunální preference dřívějšího typu: kostel-škola-hospoda, což ovšem může krom faráře, ředitele, hostinského a vedení obce významně ovlivnit i charakter regionu, např. v případě vyloučené lokality (Čada, 2015).

- Položka AH1 Všichni žáci jsou motivováni a podporováni v tom, aby dosáhli úspěchu $(2,46)$ upozorňuje na neplnění tohoto zásadního předpokladu inkluze. Nezažije-li žák ve škole úspěch, nemůže být dostatečně motivován, aby na sobě dál pracoval. Dosaženou nízkou hodnotou tohoto ukazatele je naznačeno 
nepochopení společného vzdělávání (Gottfriedová, 2021). Dispozice každého žáka si lze představit jako pomyslný „„̌̌ebřík“, který je u každého různě vysoký. Úspěchem pro žáka by nemělo být, zda vyleze stejně vysoko jako spolužáci, ale aby se každý žák přiblížil k vrcholu svého „žebříku“. Reflexe učitelů v tomto ohledu ukazuje, že učitelé se věnují žákům, kteří „lezou po žebříku“ rychle a vysoko a zanedbávají ty, kteří jsou pomalí a jejichž žebřík není tak vysoký. I tito žáci budou ale tvořit budoucnost této země.

- Položka AH2 Myšlenka inkluze je sdílena pedagogy, žáky, rodiči i ostatními zaměstnanci školy $(2,68)$ vyjadřuje nedostatečné pochopení podstaty, nedostatečné ztotožnění se s myšlenkou inkluze a její nedostatečné sdílení. Do nízké hodnoty tohoto ukazatele se jistě promítají i bariéry, které stojí v cestě inkluzi, a to jak z důvodu nedostatečně připravených podmínek, tak chybných politických rozhodnutí. Klíčové zůstává přesto nepochopení myšlenky společného vzdělávání, které mimochodem velmi připomíná Př́́hodovskou reformu školství (Příhoda, 1928), a neochota realizovat ho. Př́čin je celá řada: za sofistikovaným zdůvodněním mnohdy stojí obyčejná lidská pohodlnost, nezájem a absence jakýchkoli ideálů.

- Položka CZ1 Rozdíly mezi žáky se využívají jako zdroj pro výuku a učení $(2,69)$ vypovídá o tom, že rozdíly jsou při edukaci vnímány učiteli spíše jako minus a nikoli jako plus pro výuku. Zvládnout jinakost žáků a jejich projevů při výuce má své početní limity a klade vyšší nároky na přípravu učitelů. Jakkoli se všech devět pedagogických fakult v ČR snaží posilovat kompetence učitelů např. rozšiřováním pedagogické praxe, jedná se o dílčí aktivitu nekoordinovanou s ostatními nepedagogickými fakultami (cca 40), které mají akreditována učitelská studia (Doulík, \& Škoda, 2014). Jestliže na neučitelských fakultách připravujících učitele je věnováno pedagogické a psychologické složce jen 50 \% času ve srovnání s pedagogickými fakultami (Mareš, 2014), nelze očekávat, že předpoklad vyplývající z položky CZ1 bude naplněn. Ostatně i Komenský už věděl, že s odlišnými žáky je nutno odlišně pracovat, což dokumentoval rozčleněním na žáky bystré, co dělají radost, žáky bystré ale líné, žáky bystré ale vzpurné, na žáky s nedostatkem bystré mysli, s nedostatkem bystré mysli a líné, s nedostatkem bystré mysli a vzpurné (Komenský, 1960).

- Položka AK5 Mezi pedagogy školy a rodiči žáků existuje partnerský vztah $(2,8)$ napovídá, že se v praxi nedaří vždy tento vztah navodit, a že obě strany se projevují i jako nepřátelé, místo aby byli spojenci. Z daného ukazatele lze na obou stranách číst odlišné vnímání práv a povinností, odlišný vztah k žákovi, odlišné očekávání a cíle edukace, odlišné způsoby řešení výchovných situací apod., což se promítá i do autority učitelů. Stejně jako v předešlém případě jde o klíčového ukazatele inkluze, který lze chápat jako její nepodkročitelnou podmínku (Vomáčková et al., 2015): tam, kde rodiče nespolupracují se školou a naopak, nelze v praxi realizovat funkční inkluzi.

- Položka GZ Využívají se zdroje z celé komunity (2,92) velmi úzce souvisí s již komentovanou položkou AK7 a naznačuje, že jak personální, hmotné, finanční, časové a dalš́i zdroje z dané komunity nevnímají učitelé jako nasměrované do oblasti školství a celkově efektivně rozdělované. Lze usuzovat, že využití zdrojů v dané oblasti Litvínov, Most, Ústí podléhá i jiným prioritám, než je povinné vzdělávání v dané oblasti. Je třeba ovšem připomenout, že každé rozdělování zdrojů, by mělo být podřízeno schváleným a zveřejněným pravidlům, mělo by obsahovat požadavky, které je třeba průkazně splnit. V odvětví školství se často setkáváme s voláním po masivnějších finančních zdrojích, ale o požadavcích, které mají být z tohoto titulu splněny se hovoří jen málo (Folková, 2019).

- Položka BV1 Jmenování zaměstnanců školy do funkcí a kariérový postup pedagogů jsou spravedlivé (3,04) dokladuje, že učitelé spatřují v této oblasti rezervy. Otevřenost školy při inkluzi se dotýká všech jejích aktérů, tj. nejen žáků, ale i učitelů. Škola pro všechny by měla být nejenom vývěsním štítem, ale reálně uskutečňovaným principem: lze očekávat, že spravedlnost uplatňovaná prostřednictvím pravidel mezi učiteli se promítne i do prosazování spravedlnosti prostřednictvím pravidel mezi žáky (Roberts, \& Lindsell, 1997).

- Položka AH3 Všichni žáci jsou oceňováni $(3,05)$ bezprostředně souvisí s již komentovanou položkou AH1. Učitelé zde reflektovali, že ne všichni žáci jsou jimi chváleni či jinak oceňováni za úspěch, kterého dosáhli. Oceňování jejich pokroku se může v danou chvíli jevit jako irelevantní, nebot' jde o pokrok ve srovnání s ostatními spolužáky nepatrný. Do této položky se promítá chyba, které se učitelé dopouštějí at' již z časového nebo jiného důvodu. Prožívání úspěchu žáky, byt' sebemenšího, má průkazně motivující účinky a může sehrát klíčovou roli v posílení jejich zájmu o učení v dané oblasti (Kolář, \& Šikulová, 2007).

Výše uvedené reflexe učitelů naznačují oblasti inkluze, které učitelé vnímají jako problematické a nedostatečně na jejich škole zvládnuté. Souvisí však ale i s „proinkluzivní“ kompetencí samotných učitelů, kteří mohou ovlivňovat v tomto směru i své žáky. Jak vypovídají zahraniční studie (např. Kurniawati et al., 
2014; Godeau et al., 2010; Pančocha, 2013), učitelé statisticky významně ovlivňují své žáky, a to tím více, čím mladší žáci jsou. Innes a Diamond (1999) vyzdvihují předškolní věk jako nejefektivnější období pro učení dětí o jinakosti a pro ovlivňování jejich přístupů lidem s postižením.

\section{Závěr}

Uvedená sonda ověřovala způsob kvantifikace úrovně inkluze na třech vybraných ZŠ Ústeckého kraje pomocí upraveného dotazníku ukazatelů inkluze Bootha a Aiscowa (2011). Bylo zjištěno, že i po pěti letech implementace inkluze do škol v ČR, je řada oblastí vnímána řadovými učiteli spíše negativně a problematicky než pozitivně a bezproblémově. Svědčí o tom jak rozložení četností dle celkového skóre a směrodatné odchylky, tak hodnoty dílčích a individuálních skóre. Uvedené výsledky se různí dle konkrétních škol a upozorňují na rizika a bariéry, které zde přetrvávají a blokují optimalizaci inkluzivního prostředí v praxi. Na vzorku tří škol lze pozorovat i vliv regionálního prostředí: ZŠ Litvínov vykázala jako problematikou z hlediska inkluze podoblast AK budování komunity a CZ mobilizace zdrojů, ZŠ Most podoblast CO organizace učení a CZ mobilizace zdrojů. Naopak na ZŠS Ústí vyjádřili učitelé své uspokojení s úrovní inkluze v podoblasti BV škola pro všechny a BR podpora různorodosti. Pro školy, v nichž kolektivy usilují o pozitivní změnu na základě modelu The GROW (Svoboda, Říčan, Morvayová, \& Zilcher, 2015), představují zjišstěné výsledky zpětnou vazbu s upozorněním, kam má škola napřít svou pozornost a úsilí v budoucnosti. Jedná se o orientační sdělení, které může obsahovat subjektivní zkreslení jak ve směru nadhodnocení, tak podhodnocení reálných podmínek inkluze, což nelze pustit ze zřetele. V dalším šetření by proto bylo žádoucí násobně zvětšit rozsah výzkumného vzorku a posílit jeho různorodost zastoupením z jiných krajů, aby byla co nejvíce eliminována chyba tohoto charakteru.

Příspěvek vznikl v rámci projektu SGS 4320115 2003-43 01 Rozvoj disponibilit žáka a jeho měření v běžné pedagogické praxi ZŠ na Univerzitě J. E. Purkyně v Ústí nad Labem.

\section{Literatura}

Adamus, P. (2015). Metodika hodnocení kvality inkluzivní školy: Evaluační nástroj hodnocení kvality inkluzivní školy. Slezská univerzita v Opavě.

Adamus, P., Zezulková, E., Kaleja, M., \& Franiok, P. (2016). Inkluzivní vzdělávání v kontextu proměn českého školstuí. Ostravská univerzita.

Ainscow, M., \& César, M. (2006). Inclusive education ten years after Salamanca: Settin the agenda, European Journal of Psychology of Education, 21(3), 231-238.

Ajzen, I., \& Fishbein, M. (2005). The influence of attitudes on behavior. In D. Allbarracin, B. T., Johnson, M. P. Zanna (Eds.), The handbook of attitudes (pp.173-221). Mahwah, NJ: Lawrence Erlbaum Associates.

Booth, T. \& Ainscow, M. (2007, 2011). Index for inclusion: Developing learning and participation in schools. Centre for Studies on Inclusive Education.

Čada, K. (Ed.) (2015). Analýza sociálně vyloučených lokalit v ČR. Dopady a potřeby inkluzivních politik a projektů. GAC spol. s. r. 0. https://www.esfcr.cz/documents/ 21802/791224/Anal\%C3\%BDza+soci\%C3\%A1ln\%C4\%9B+vylou\%C4\%8Den\%C3\%BDch+lokalit+v+\%C4\%8CR.

Doulík, P., \& Škoda, J. (2014). Příprava učitelů v kontextu kontinuální optimalizace. Pedagogická orientace 24(5), 818-837.

Folková,J.(2019). Kariérnířád učitelů.EdTechKisk. https://medium.com/edtech-kisk/kari\%C3\%A9rn\%C3\%AD-\%C5\%99\%C3\%A1d-u\%C4\%8Ditel\%C5\%AF-4a187d0574cd.

Godeau, E., et al. (2010). Improving attitudes toward children with disabilities in school contect: A cluster randomized intervention study. Developmental Medicine \& Child Neurology, 52(10), 531-542.

Gottfriedová, M. (2021, 30. srpna). Škola má každé dítě rozuíjet na maximum. http://www.romea.cz/cz/ zpravodajstvi/marie-gottfriedova

Hájková, V., \& Strnadová, I. (2010). Inkluzivní vzdělávání: Teorie a praxe. Grada Publishing.

Innes, F.K. \& Diamond, K.E. (1999). Typically developing children's s interactions with peers with disabilities: Relationships between mothers' comments and children's ideas about disabilities. Topics in Early Childhood Special Education, 19(2),103-111.

Kolář, Z. \& Šikulová, R. (2007). Vyučování jako dialog. Grada.

Komenský, J. A. (1960). Pravidla chování. In Vybrané spisy Jana Amose Komenského, sv. 2. SPN. 
Kratochvílová, J. (2013). Inkluzivní vzdělávání v české primární škole teorie, praxe, výzkum. Masarykova univerzita.

Kurniawati, F. et al. (2014). Characteristics of primary teacher training programmes on inclusion: a literature focus. Educational Research 56(3), 310-326. http://dx.doi.org/10.1080/00131881.2014.93455.5.

Lukas, J. (2012). Připravenost školy k inkluzivnímu vzdělávání: Dotazník pro učitele. NUV

Odom, S. L., Buysse, V., \& Soukakou, E. (2011). Inclusion for young children with disabilities: A quarter century of research perspectives. Journal of Early Intervention 33(4), 344-356. https://journals.sagepub.com/doi/abs/10.1177/1053815111430094.

Mareš, J. (2014). Koncepce pregraduální přípravy učitelo̊ základních a středních škol. http://aplikace.msmt. cz/ak/koncepce1.htm.

MŠMT (2021). Individuální integrace do běžných tříd základních škol. Tabulka B9.1.3 https://www.msmt. cz.

Mühlpachr, P. (Ed.) (2008). Speciální pedagogika v interdisciplinárních a multidisciplinárních souvislostech. Masarykova univerzita.

Mukopahdyay, S. (2014). Botswana primary schools teachers' perception of inclusion of learners with special educational needs. Journal of Research in Special Educational Needs, 14(1), 33-42.

Pančocha, K.(2013). Postoje veřejnosti k sociální participaci osob s postižením. Habilitační práce. Masarykova univerzita.

Petlák, E. (2009), Zásady mozgovo kompatibilného vyučovania a učenia. In Petlák, E., Valábik, D., \& Zajacová, J. (Eds.) Vyučovanie - mozog - žiak. Iris.

Pettigrew, T.F. \& Tropp, L.R. (2008). How does intergroup contact reduce prejudice? Meta-analytick tests of three mediators. Journal of Personality and Social Psychology, 90(5), 751-783. http://doi. org/10.1037/0022-3514.90.5.751.

Prudký, L. (2009). Inventura hodnot, výsledky sociologických výzkumů hodnot ve společnosti České republiky. Academia.

Příhoda, V. (1928). Jednotná škola. Její možnosti dnes a zítra. Školské reformy 12.

Roberts, C.M., Lindsell, J.S. (1997). Children's Attitudes and Behavioral Intentions towards Peers with Disabilities. International Journal of Disability. Development and Education, 44(2), 19-27.

Spilková, V., \& Tomková, A. et al. (2010). Kvalita učitele a profesní standard.

Svoboda, Z., Říčan, J., Morvayová, P., \& Zilcher, L. (2015). Metodika tvorby strategického plánu pro vytváření inkluzivního prostředí školy. Univerzita J. E. Purkyně.

Svoboda, Z., Zilcher, L., Němec, Z., Felcmanová, L., Smolík, A., Vostrý, M., \& Lanková, B. (2020). Koordinátor inkluze ve škole. Univerzita J. E. Purkyně.

Šauerová, M., Špačková, K., \& Nechlebová, E. (2012). Speciální pedagogika v praxi. Komplexní péče o děti se SPUCH. Grada.

Tannenbergerová, M. (2013). Inkluze v základní škole: Vývoj a ověřování evaluačního nástroje. Disertační práce. Masarykova univerzita.http://is.muni.cz/th/105251/pedf_d/Plny_text_prace.pdf.

Tannenbergerová, M. (2016). Průvodce školní inkluzí, aneb, Jak vypadá kvalitní základní škola současnosti? Wolters Kluwer.

Tannenbergerová, M., Svoboda, Z., Zilcher, L., \& Smolík, A. (2015). Autoevaluace školy v oblasti inkluze. Univerzita J. E. Purkyně.

Vomáčková, H. et al. (2015). Výzkumný pohled na inkluzi a její determinanty. UJEP.

Vomáčková, H. \& Cihlář, D. (2015). Regionální disonance v hodnotových soudech adolescentů. Univerzita J. E. Purkyně.

Vomáčková, H. \& Chytrý, V. (2019). Žáci školou povinní: vícekriteriální sonda. UJEP.

Zilcher, L., \& Říčan, J. (2014). Multikulturní výchova jako cesta k inkluzi. In Rabensteiner, P.M., \& Rabensteiner, G. Challenges. 6 ed. Baltmannsweiler: Schneider Verlag Hohengehren, s. 178-191.

Zilcher, L., \& Svoboda, Z. (2019). Inkluzivní vzdělávání. Grada. 


\section{Informace o autorovi}

\section{doc. Ing. Helena Vomáčková, CSc.}

Vysokoškolská učitelka na katedře speciální a sociální pedagogiky Pedagogické fakulty Univerzity J. E. Purkyně v Ústí nad Labem. Zabývá se problematikou inkluze a její optimalizace zejména v podmínkách povinného vzdělávání s prioritním zaměřením na Ústecký kraj a jeho specifika. Přínos pro obor lze spatřovat v obohacování teorie praxí a naopak.

Kontaktní údaje:

Telefon: +420 475282167

Email: helena.vomackova@ujep.cz 